\title{
Political Dynamics of Muhammadiyah and Its Relevance to the Concept of the State in Islam
}

\author{
Kasman Bakry' ${ }^{1}$ Ambo Asse ${ }^{2}$, Darussalam Syamsuddin ${ }^{3}$, \\ Kasjim Salenda ${ }^{4}$, Roziana Shaari ${ }^{5}$
}

\begin{abstract}
Political Dynamics of Muhammadiyab and Its Relevance to The Concept of The State in Islam. This study describes the political dynamics of Muhammadiyah and its relevance to the constitutional concept from an Islamic political perspective. This research uses a descriptive, and historical approach. The results of the study find out: First, the characteristics of an Islamic state are applying God's law, adopting a form of leadership, being universal, not totalitarian, and applying a humane leadership pattern. This character is supported by a leadership system based on basic principles in the Islamic state (al-mabda 'al-asâsîfi dawlah al-Islamiyyah) which includes: trustworthiness (al-amânah), deliberation (alsyûrâ), equality (al-musâwâ), justice (al-'adâlah), and plurality (al-ta 'addudiyya). Second, the Muhammadiyah doctrine originates from the al-Qur'an and al-Hadith and contains a system of beliefs, thoughts, and actions which, as a whole, are accumulated into the ideology and values of the Muhammadiyah movement. This doctrine is then outlined in Muhammadiyah's statute and Bylaws (AD/ART) and covers all steps and strategies for the struggle, personality, beliefs, and way of life of Muhammadiyah. Third, political theology and universal and fundamental religious understanding serve as guidelines, and at the same time, as the blueprint for Muhammadiyah's political midset which is implemented through political and cultural channels in the realm of high, allocative politics.
\end{abstract}

Keywords: Political Dynamics of Muhammadiyah, Islamic constitutional concept

\begin{abstract}
Abstrak: Dinamika Politik Muhammadiyah dan Relevansinya dengan Konsep Negara dalam Islam. Kajian ini mendeskripsikan dinamika politik Muhammadiyah dan relevansinya dengan konsep ketatanegaraan dari perspektif politik Islam. Penelitian ini menggunakan metode deskriptif dan pendekatan sejarah. Hasil penelitian menemukan: Pertama, ciri-ciri negara Islam adalah menerapkan hukum Tuhan, mengadopsi satu bentuk kepemimpinan, bersifat universal, tidak totaliter, dan menerapkan pola kepemimpinan yang manusiawi. Karakter ini didukung oleh sistem kepemimpinan yang didasarkan pada prinsip-prinsip dasar negara Islam (al-mabda 'al-asâsî fi dawlah al-Islamiyyah) yang meliputi: keadilan (al-'adâlah), terpercaya(al-amânah), musyawarah (al-syûrâ), kesetaraan (al-musâwâ), dan pluralitas (alta 'addudiyya). Kedua, doktrin Muhammadiyah yang bersumber dari al-Qur'an dan alHadits mengandung sistem keyakinan, pemikiran, dan tindakan yang secara keseluruhan terakumulasi dalam ideologi dan nilai-nilai gerakan Muhammadiyah. Ajaran ini kemudian dituangkan dalam Anggaran Dasar dan Anggaran Rumah Tangga (AD/ART) Muhammadiyah
\end{abstract}

\footnotetext{
1,2,3,4Universitas Islam Negeri Alaudin Makassar

${ }^{5}$ Universitas Teknologi Malaysia

E-mail: ${ }^{1}$ kasmanbakry@stiba.ac.id , ${ }^{2}$ amboasse22uin@yahoo.co.id, ${ }^{3}$ darussalam_syamsuddin@yahoo.com,

${ }^{4}$ kasjim.salenda@gmail.com, ${ }^{5}$ roozianautm@gmail.com
} 
dan menaungi segenap langkah dan strategi perjuangan, kepribadian, keyakinan dan jalan hidup Muhammadiyah. Ketiga, teologi politik dan pemahaman keagamaan yang universal dan fundamental menjadi pedoman dan sekaligus cetak biru midset politik Muhammadiyah yang diimplementasikan melalui jalur politik dan budaya dalam ranah politik tinggi atau politik alokatif.

Kata Kunci: Dinamika Politik Muhammadiyah, Konsep ketatanegaraan Islam

\section{Introduction}

The relationship between religion and the state in political Islam is not only visible in the application of Islamic political principles in the government and state system, but is also externally influenced by historical, social, cultural, and economic backgrounds, as well as mixed thoughts in political and legal traditions. within the Muslim community itself. ${ }^{1}$ This seems to support the view that in the initial phase of its emergence, Islam was often associated with the triumphant experience in the political field. ${ }^{2}$

As social beings, human existence is very important in carrying out the role of leadership (Imamat) and political responsibility to maintain goodness, security, and justice in society. For this reason, all aspects of human life must be kept away from various conflicts and chaos caused by the many human desires that are articulated differently, causing conflicts between one another, sometimes even ending in war.

The differences in political order and traditions between Muslims and non-Muslims throughout the history of human civilization have prompted the attention of political scientists to comprehensively discuss various aspects of Islamic statehood which include the concepts of the state, the necessity of a state, the basic philosophy of the state, the rights and obligations of the head of state, state institutions and administration, relations between countries, rights and obligations of the people and

${ }^{1}$ Philip K. Hitti, History of The Arabs (London: Mac Millan, 1974), p. 139.

2 Ahmad Syafi'i Ma'arif, Islam Dan Masalah Ketatanegaraan (Jakarta: Bulan Bintang, 1993), p. i. 
various other aspects, including matters of war ethics. The above aspects have become material for in-depth studies resulting in some works in the field of constitutional politics both in theory and practice and linking them to Syara sources; namely the Qur'an and Hadith. ${ }^{3}$ These scientists believe that the verses of the Qur'an and al-Hadith are a fundamental basis for the development of political concepts that must be interpreted, analyzed, and understood comprehensively through various methods and approaches. The Qur'an and Hadith are believed to contain universal principles that can be applied in all aspects of human life, including solving various problems that arise in social and political life. In this context, they believe that the verses of the Qur'an as a fundamental basis for the development of political concepts must be interpreted, analyzed, and understood comprehensively through various methods and approaches.

The universal political principles of Islam can be identified in a number of verses of the Qur'an which are interrelated in a systemic conceptual form and structure. For example, the concept of Khilafah on earth, as stated in QS. al-Baqarah/2:30; QS. al-Nur/24: 55; QS. al-Naml/27: 62; QS. al-Shâd/38; QS. al-Anầm/6: 165: the concept of law and justice, as stated in QS. al-Nisât/4: 58, 105, 135; QS. al-Mâidah/5: 6; the leadership principles, as stated in the QS. Âli Imrân/3: 118; QS. al-Nisâ/4: 49; QS. al-Syu'ara/26: 150-152: the issues of leadership and deliberation, as mentioned in the QS. Âli Imrân/3: 159; QS. al-Syûrâ/42: 38; the principle of unity and brotherhood, as mentioned in QS. Âli Imrân/3: 103; QS. al-Hujurât/49: 10: the principle of equality, mentioned in QS. al-Nisâa/4: 1; the principle of helping and defending the weak, mentioned in QS. al-Mâidah/5: 2; QS. al-Taubah/9: 11; QS. al-Balad/90: 12-16; the principles of war and peace, mentioned in QS. al-Nisâ'/4: 89-90; QS. al-Anfâl/8: 61; and so forth. The arguments mentioned above indeed do not explicitly oblige society to establish a state or form a government; but the existence

${ }^{3}$ Abul 'Ala al-Maududi, Islam and Constitution (Lahore: Lahore University Press, 1992), pp. 579-480. 
of orders to obey the leader, deliberation, act fairly, trustworthy, and responsibly, as well as other political moral principles, all of which can be understood implicitly as orders. Because in the political concept of Islamic law there is a rule which reads: ma la yatimmu al-wujub illa bihi fahuwa al-wajib. (everything without which an obligation is imperfect is mandatory). ${ }^{4}$

Al-Qur'an and Hadith command the realization of universal principles which include equality, brotherhood, justice, benefit, and so on, as was done by Prophet Muhammad SAW during his lifetime. In the context of the State of Medina, the Prophet Muhammad explained to his followers that not everything he did came from the commands of al-Qur'an, including the establishment of the state of Medina. He only emphasized to his followers to ensure that the political system is built based on the universal principles of Islamic politics derived from al-Qur'an and Hadith. ${ }^{5}$

The Islamic political concept formulated by the Prophet Muhammad SAW in the context of the State of Medina, including what was practiced by Khulafa al-Rashidin in the early days of Islam, was multiinterpretative, because it was motivated by historical products. Some scholars argue that from the past until now there has been no concept of theocracy in Islam except the formulation of an Islamic political system as practiced at the time of the Prophet Muhammad. As a result, there is a debate whether Islam adheres to the concept of theocracy or not. Historians agree that the ideal theocracy was only applied when the Prophet was still alive. After he died the concept changed from theocracy to theo-democracy. This started from the election of the first caliph, Abu Bakr Ash-Siddiq. Abu Bakr was chosen based on the results of the deliberations of the friends. In the election process which will determine who can replace the Prophet's position as the leader of the ummah, there has been quite a heated debate between

${ }^{4}$ Hamid Fahmy Zarkasy, 'Identitas Dan Problem Politik', Jurnal Pemikiran Dan Peradaban Islam ISLAMIA, 1.2 (2009), p. 5.

${ }^{5}$ Hamid Fahmy Zarkasy, p. 6. 
the Muhajirin and the Ansar. Although at first, they persisted in their respective thoughts, in the end, they agreed to choose Abu Bakr AshSiddiq as the leader of the ummah through a process of deliberation. From this historical background, scientists have found the fact that the incident did not only discuss who deserves to be appointed as a leader but also includes how to choose a leader who is following Islamic norms. ${ }^{6}$ The political agreement reached by the companions in the election of the Caliph Abu Bakr can be seen as a product of political thought (ijtihad $f i$ al-siyasi) which emerged as a solution in solving a political problem. The event at Tsaqifah Bani Saidah is an implementation of the concept of deliberation (shura) which first appeared in the history of Islamic politics after the Prophet's death and is an important milestone for the history of Islamic politics as well as a fundamental foundation for developing an Islamic political system for the next period. ${ }^{7}$ Indeed, the most prominent political problem after the Prophet Muhammad's death was the problem of leadership; Therefore it is not surprising that later on, this topic became the focus of discussion of Muslim scholars because it was inseparable from the character of the Islamic community which placed the role of the leader in a strategic and central position.

Referring to the above description, it can be said that the issue of leadership has always been the main topic in Islamic political discourse from the past until now. Each scholar has a different opinion in explaining this topic. Some of them focus their opinions through historical perspectives and others refer to various perspectives such as normative, sociological, anthropological, etc. This article will discuss the political dynamics of Muhammadiyah and its relevance to the concept of the state from the perspective of Islamic political law.

${ }^{6}$ W. Montgomery Watt, Islamic Political Thought (Edinburgh: Edinburgh University Press, 1960); See also Donald Eugene Smith, Religion and Political Development (Boston: Little, Brown and Co, 1978).

7 Hamid Fahmy Zarkasy, p. 7. 


\section{Method}

This study uses a descriptive-analytical method using a historical normative approach. Its purpose is to explain the political dynamics of Muhammadiyah and its relevance to the concept of a state in the perspective of Islamic political law. Sources and data collection techniques refer to a variety of literature, documents, and other written sources related to the research topic. Data analysis uses the deductive method, namely explaining the results of research and discussion through a general to a specific approach to produce conclusions.

\section{The Concept of Islamic Political System in Islamic History}

After the leadership of the Prophet Muhammad and Khulafâ al-Râsyidin, the political map and the Islamic government system underwent very significant changes. The principle of democracy (alshura) which was originally practiced to elect leaders in the early Islamic government system turned into an Islamic dynastic system in the hands of Muslim rulers. These changes began when Muawiyah came to power and continued into the next dynasty, namely the Abbasids and the Ottoman empire. ${ }^{8}$ According to some political analysts, this change in the Islamic government system is influenced by several factors such as geography, culture, traditions, including conflicts of political interest among Muslim leaders.

Entering the medieval Islamic era, the political power of Islam experienced a decline due to various factors, both internal and external. Abuse of power, political conflict, disharmony, and disintegration are the internal backgrounds of the decline in the political power of Islam. In addition, the Hulagu-Mongol invasion of the Abbassid Empire and the long-lasting Crusade between Muslims and Western Christians also influenced the decline in the political power of Islam. After the end of the caliphate period which was marked by the collapse of the Ottoman

${ }^{8}$ Humprey, Islamic History (USA: Harvard University Press, 2000), p. 128; See also Jalaludin Suyuti Pulungan, Fikih Siyasah: Ajaran, Sejarah, Dan Pemikiran, (Jakarta: Rajawali Press, 1994), p. 7. 
Empire, the influence of Western political culture began to penetrate. The political order of the Islamic world, both through colonial politics and from Muslim scholars who returned home after completing their studies in the Western world.

The entry of Western political thought into the Islamic world has generated mixed responses from Muslim scholars. Some of them are a priori and anti-Western, some accept it as a whole, and some others try to reconcile it by seeking positive values from Western civilization and thought and discarding values that are contrary to Islam. ${ }^{9}$ Those who reject the concept of Western politics argue that Islam has its own ideal concept/system of government and is based on Islamic teachings as practiced during the time of the Khulafa Rashidun. They consider that the system of government outside of the Caliphate or from outside of Islam should not be adopted by Muslims anytime and anywhere because it does not have a reference that comes from the al-Qur'an and As-Sunnah.

On the other hand, the second group considers that the political system applied by Western society is worthy of being emulated. This is based on the reason that the West is a representation of democracy and a model for advanced society in modern times so that Muslims can imitate or adopt a good democratic and political system from the West. Meanwhile, for the third group, the concept of state and government is seen as being within the scope of the issue of ijtihad. They think that the main objective of the government is to bring benefit to society. For this reason, on the one hand, they are not allergic to the Western political system; On the other hand, they selectively filter it and only take the positive values from the Western political tradition and get rid of the negative side. In other words, the special characteristic of this group is that they do not completely reject the concept of Western democracy but also do not accept it entirely because they see democracy

${ }^{9}$ Robert, N. Bellah, Beyond Belief: Essay on Religion in a Post-Traditionalist World (Berkeley and Los Angeles: University of California Press, 1991), p. 12. 
as relevant and following the principles of shura in Islam. ${ }^{10}$

Based on historical facts, the political system and Islamic government have been formulated by some Islamic thinkers from the first period to the medieval period as has been done by Abû al(364-450 H/975- 1059 AD), Abû Hamîd Muhammad al -Ghazâlî (450505 H/1058-1111 AD), Ahmad bin Taimiyah (661-728 H/1263-1328 AD), Abdurrahmân bin Khaldûn (732-808 H/1332-1406 AD), and so on. The thoughts of these scholars not only contain the formulation of a political system in the perspective of Islamic law (figh al-siyasah alsyar'iyyah) but also describe their views on issues of politics, governance, leadership, and the state that is relevant to the political atmosphere developing at that point. These formulations were subsequently used by contemporary scholars to reconstruct the doctrine of Islamic law by redefining the concept of Islamic politics to suit modern times. Consequently, the current political discourse and practice of Islam no longer similar to what developed in the previous period (classical and medieval periods) even though the theories and concepts of Islamic politics that have been built and developed by past Muslim scholars remain the main reference in reconstructing. modern Islamic political system. This trend may be influenced by two factors: first, Muslims have lost the internal dynamics of their scientific tradition, and second, the swift flow and hegemony of Western thought have influenced the practices and thoughts of Islamic political scientists in many Muslim countries.

\section{The Implementation of Islamic Political System in Muhammadiyah Perspective}

The traces of Islamic political thought in the medieval period have influenced the political discussion (ijtihad al-siyasi) in several contemporary religious organizations in Indonesia. This can be seen in the dynamics of

${ }^{10}$ Muhammad Iqbal \& Amin Husein Nasution, Pemikiran Politik Islam Dari Masa Klasik Hingga Indonesia Kontemporer, (Jakarta: Kencana Prenada Media Group). 
Islamic political discourse in one of the religious organizations that has a significant number of followers, namely Muhammadiyah.

Muhammadiyah was born and developed because of the role of its leaders, cadres, and members who have high militancy. Since the K.H. Ahmad Dahlan, who pioneered the establishment of Muhammadiyah to the next generation of leadership, was seen by the persistence of the pioneers (al-sâbiqûna al-awwalûn) in bringing this organization to a high position and a place of honor, making Muhammadiyah one of the second largest modern Islamic movement organizations in Indonesia after Nahdhatul 'Ulama (NU). ${ }^{11}$ At the member and cadre level, militancy can be seen in the attitudes and behavior of members both individually and collectively because of the demands of the community so that each Muhammadiyah cadre, especially those promoted to become a leader, becomes a good figure, has integrity, is trustworthy and has an exemplary attitude (uswah hasanah) for society at large.

Judging from the context of thought, the Muhammadiyah movement that was built by K.H. Ahmad Dahlan is one of the connecting links for the Islamic reform movement at the international level that has been started by well-known Muslim thinkers such as Ibn Taymiyyah, Ibn alQayyim al-Jauziyyah, Muhammad bin Abdul Wahhâb, Sayid Jamâluddîn al-Afghânî, and Muhammad Abduh. Muhammad Abduh's influence in the body of Muhammadiyah is identified through his thoughts contained in his famous commentary book, Tafsir al-Manâr, which was later edited by his student, Râsyid Ridhâ, and al-Urwah al-Wutsqâ magazine. However, Azyumardi Azra denied the influence of this thought. According to Azra, the actual influence was not from all of Abduh's thoughts, because in terms of theology (aqidah), Muhammadiyah was closer to Asy'ariyah theology than Abduh's theology which was closer to Mu'tazilah theology. ${ }^{12}$

${ }^{11}$ Haedar Nasir, Dinamisasi Gerakan Muhammadiyah: Agenda Strategis Abad Kedua (Yogyakarta: Suara Muhammadiyah, 2015), p. 99.

${ }_{12}$ Pergolakan Politik Islam Dari Fundamentalisme, Modernisme, Hingga Post-Modernisme (Jakarta: Paramadina, 1995). 
Muhammadiyah does not at all follow Muhammad Abduh's theology and there is no similarity between the two. Abduh's theology is Mu'tazilite and tends to be rational, while Muhammadiyah's theology is Ash'ariyah and tends to be traditional. ${ }^{13}$

Apart from the differences in theological characteristics as Azra identified, the Muhammadiyah organization has made a major contribution in developing Indonesia, including providing a role and color in the dynamics of politics and state leadership. The spirit and the Islamic reform movement initiated by K.H. Ahmad Dahlan in the homeland is similar to the Islamic reforms carried out by Ibn Taimiyyah and Muhammad bin 'Abdul Wahhâb in the last medieval period, even the identity of Muhammadiyah can be said to be the founding father of the Islamic reform movement in Indonesia both politically and theologically. This is shown by the various efforts of Muhammadiyah in the movement to purify Islamic creeds in the form of eradicating Takhayyul, Bid'ah, and Khurafât among the Muslim community, which is similar to the da'wah movement carried out by Ibn Taimiyyah and Muhammad bin 'Abdul Wahhâb in the past.

According to Ahmad Najib Burhani, the term "Islamic Puritanism" is sometimes labeled as Islamic purification movements such as those practiced by Muhammadiyah. The Islamic Puritanism movement which is often interpreted as the concept of returning to al-Qur'an and Hadith (al-Rujû ilâ al-Qurân wa al-Sunnah) is related to the al-Muwahhidûn or Wahabi movement led by Muhammad bin Abdul Wahhab in Saudi Arabia. ${ }^{14}$ Although according to Burhani there are similarities in characteristics and tendencies between the Wahabi movement and Muhammadiyah organizations in Indonesia, his opinion still needs to be further criticized by looking at the substance of historical values and threads. For Muhammadiyah, this labeling is not a problem, because,

${ }^{13}$ Musthafa Kamal Pasha \& Ahmad Adaby Darban, Muhammadiyah Sebagai Gerakan Islam (Yogyakarta: PPI, Universitas Muhammadiyah Yogyakarta, 2000), p. 105.

${ }^{14}$ Ahmad Najib Burhani, Muhammadiyah Progressing: A Shift from Puritanism to Cosmopolitanism (Bandung: PT. Mizan Pustaka, 2016), p. 35. 
like Buya Hamka's statement at the Muhammadiyah Congress in 1930, official travel in the Muhammadiyah movement is an honor for all Muhammadiyah members. ${ }^{15}$

In the political field, the implementation of the Islamic political system in the perspective of Muhammadiyah was initially based on the spirit of the Islamic puritanism movement associated with the concept of returning to al-Qur'an and Hadith (al-Rujû ilâ al-Qurân wa al-Sunnah). However, in its development, the Islamic reform movement promoted by Muhammadiyah also touched on the political and constitutional aspects of Indonesia. Muhammadiyah's response to the issue of leadership in Islam must be determined through deliberation to reach a consensus under the principles of sh ura in Islam. In brief unlike the current political system which tends to place Islamic politics in practical and despicable politics, Muhammadiyah is more likely to play its role in the realm of high politics or social monotheism which is interpreted as noble politics and has an ethical dimension.

The characteristics of an Islamic state in the view of Muhammadiyah are applying God's law, adopting a form of leadership, being universal, not totalitarian, and applying a human leadership pattern. This character is supported by a leadership system based on the basic principles of an Islamic state (al-mabda 'al-asâsî fi dawlah al-Islamiyyah) which includes: justice (al-'adâlah), trustworthiness (al-amânah), deliberation (al-syûrâ), equality (al-musâwâ), and a plurality (al-ta 'addudiyya). Muhammadiyah doctrine, which is derived from al-Qur'an and al-Hadith, crystallizes the beliefs, thoughts, and actions that as a whole are accumulated in the ideology and values of the Muhammadiyah movement. These values are then embodied in Muhammadiyah's Articles of Association and Bylaws (AD/ART) which cover all steps and strategies of struggle, personality, beliefs, and organizational life path. Political theology and religious understanding which are universal and fundamental are the guidelines and at the same time the blueprint for Muhammadiyah's political midset

15 Hamka, Moehammadijah Melaloei Tiga Zaman (West Soematra: Markaz Idarah Moehammadijah, 1946), p. 108. 
which is implemented through political and cultural channels in the realm of higher politics or allocative politics.

Muhammadiyah is always consistent and focuses on issues of Islam and nationality and does not formally involve itself in Indonesian practical politics. This is based on the main principle that Muhammadiyah is not an Islamic organization that is subordinate to certain political parties. Muhammadiyah's neutral stance has enabled the organization to become a voice for the aspirations of the majority of Indonesian Muslims. Even though it is neutral, Muhammadiyah is consistent in being responsive and open in responding to various problems and political dynamics that occur in the country as well as participating in the stage of democracy in Indonesia. This attitude was shown by the Muhammadiyah leadership through instructions to all members and cadres to participate in the electoral process; considering that elections are the only democratic means to elect a leader who will determine the direction and future of a country. Instructions issued by the Muhammadiyah Central Leadership were obeyed by all Muhammadiyah leaders and cadres at lower levels, including from youths who then issued a Joint Statement Letter to strengthen and strengthen Muhammadiyah's official neutrality position in the 2019 Election. ${ }^{16}$

\section{Conclusion}

Based on the above discussion, it can be concluded that: first, the fundamental concept of an Islamic state (al-mabda 'al-asâsî fi dawlah al-Islamiyyah) in the political perspective of Muhammadiyah consists of several universal principles such as trustworthiness (al-amânah), discussion (al-syûrâ), equality (al-musâwâ), justice (al-'adâlah), and a plurality (al-ta 'addudiyyah); Second, the Muhammadiyah doctrine contains a system of beliefs, thoughts, and actions which collectively accumulate into the values of the movement. In Muhammadiyah's view, an Islamic state is a universal understanding that must be enforced in practice under divine law and must also be implemented into

${ }^{16}$ Hamid Fahmy Zarkasy, p. 8. 
state legislation; Third, the fundamental and universal concepts of political theology and democracy become Muhammadiyah's Blueprint and Guidelines in the Indonesian political mindset, which can be implemented in all aspects of state life by eliminating the practice of dictatorship or tyranny in the political system.

\section{Bibliography}

Abul 'Ala al-Maududi, Islam and Constitution (Lahore: Lahore University Press, 1992)

Ahmad Najib Burhani, Muhammadiyah Progressing: A Shift from Puritanism to Cosmopolitanism (Bandung: PT. Mizan Pustaka, 2016)

Ahmad Syafi'i Ma'arif, Islam Dan Masalah Ketatanegaraan (Jakarta: Bulan Bintang, 1993)

Donald Eugene Smith, Religion and Political Development (Boston: Little, Brown and Co, 1978)

Haedar Nasir, Dinamisasi Gerakan Muhammadiyah: Agenda Strategis Abad Kedua (Yogyakarta: Suara Muhammadiyah, 2015)

Hamid Fahmy Zarkasy, 'Identitas Dan Problem Politik', Jurnal Pemikiran Dan Peradaban Islam ISLAMIA, 1.2 (2009)

Hamka, Moehammadijah Melaloei Tiga Zaman (West Soematra: Markaz Idarah Moehammadijah, 1946)

Humprey, Islamic History (USA: Harvard University Press, 2000)

Jalaludin Suyuti Pulungan, Fikih Siyasah: Ajaran, Sejarah, Dan Pemikiran, (Jakarta: Rajawali Press, 1994)

Muhammad Iqbal \& Amin Husein Nasution, Pemikiran Politik Islam Dari Masa Klasik Hingga Indonesia Kontemporer, (Jakarta: Kencana Prenada Media Group)

Musthafa Kamal Pasha \& Ahmad Adaby Darban, Muhammadiyah Sebagai Gerakan Islam (Yogyakarta: PPI, Universitas Muhammadiyah Yogyakarta, 2000)

Pergolakan Politik Islam Dari Fundamentalisme, Modernisme, Hingga PostModernisme (Jakarta: Paramadina, 1995) 
Philip K. Hitti, History of The Arabs (London: Mac Millan, 1974)

Robert, N. Bellah, Beyond Belief: Essay on Religion in a Post-Traditionalist World (Berkeley and Los Angeles: University of California Press, 1991)

W. Montgomery Watt, Islamic Political Thought (Edinburgh: Edinburgh University Press, 1960) 